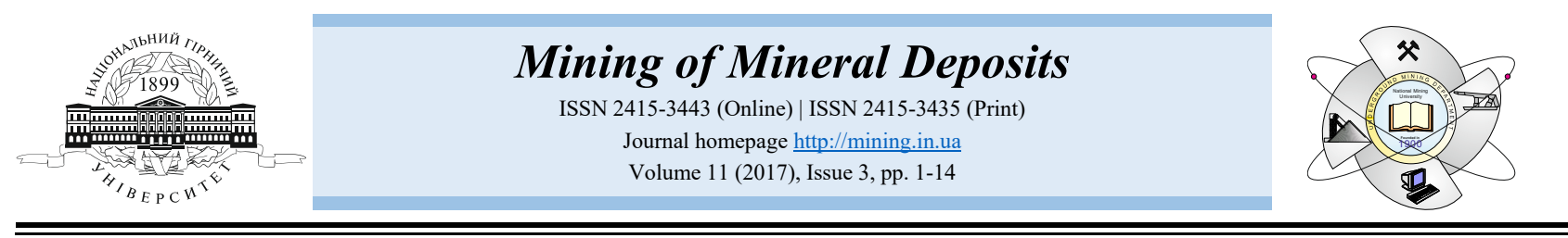

UDC 622.278

https://doi.org/10.15407/mining11.03.001

\title{
THE EFFECT OF INCREASING THE WATER CONTENT ON ROCKS CHARACTERISTICS FROM ŞUIOR, ROMANIA
}

\author{
M. Toderas ${ }^{1}$, R. Moraru ${ }^{2 *}$ \\ ${ }^{I}$ Mining Engineering, Surveying and Civil Engineering Department, University of Petrosani, Petrosani, Romania \\ ${ }^{2}$ Management and Industrial Engineering Department, University of Petrosani, Petrosani, Romania \\ *Corresponding author: e-mail roland moraru@yahoo.com, tel.+40723624105, fax: +40254543491
}

\section{ВПЛИВ ПІДВИЩЕНОЇ ОБВОДНЕНОСТІ НА ВЛАСТИВОСТІ ГІРСЬКИХ ПОРІД РОДОВИЩА ШУЙОР, РУМУНІЯ}

\author{
М. Тодерас ${ }^{1}$, Р. Морару ${ }^{2 *}$ \\ ${ }^{1}$ Кафедра гірництва, геодезії та цивільної інженерії, Університет Петросані, Петросані, Румунія \\ ${ }^{2}$ Кафедра управління та промислової інженерії, Університет Петросані, Петросані, Румунія \\ *Biдповідальний автор: e-mail roland moraru@yahoo.com, тел. +40723624105, факс: +40254543491
}

\begin{abstract}
Purpose. Generation of relative humidity fluctuations lead to a further decrease in the resistance of rocks, which involves the swift evacuation of groundwater from mining works. For andesitic rocks strongly hydrothermal altered it was found an irreversible phenomenon of the effect of humidity upon their strength, while this phenomenon is accompanied by an alteration. Natural humidity content at saturation and absorption coefficient of rock specimens studied ranged within large limits, average kinetics absorption by changing from one type of rock to another, some rocks could not reach the degree of saturation because they were disaggregated.
\end{abstract}

Methods. Establishing the rocks characteristics from Şuior mine, in the context of underground microclimate conditions and their interaction with water taking into account the determinative anisotropy and the degree of heterotrophy.

Findings. Some of the mining works with straight walled profiles, vaulted ceiling and unsupported floor were executed in rocks with pronounced trends towards deterioration and swelling of floors; given that, the rocks contain insertions of kaolin andesite, have shown a tendency to swelling of floor, which required the use of circular profiles and horseshoe-shaped profiles with enclosed floor. Observations have highlighted that the deformations of the floor are not due only to the fact that the works are located in rocks with low resistance, but also because the water is accumulated in the floor of these works, changing in a short time the mechanical properties of the rocks. Swelling of the floor is the consequence of intensive water-rock action, having the effect of misalignment of the floor, destructive effect upon the foundation and of support base, this attempt a horizontal displacement towards the interior of the gallery, unbalancing the support.

Originality. For the rocks from Şuior, protecting with synthetic resin is the optimal method, which is confirmed by the good behavior of the resins as insulating protection in order to maintain the characteristics of these unaltered rocks.

Practical implications. Under the influence action of water and underground climate, most of the rocks, with the exception of porphyritic andesite with hipersten, degrades and reduces its mechanical strengths and elastic characteristics. In order to maintain these rocks to initial parameters, methods will be used to protect, to strengthen. Alteration created by water effect has a significant influence on the characteristics of strength and deformation, effect that has direct implications on the stability of the mining works performed in the rocks from Şuior.

Keywords: anisotropy, alteration, humidity, swelling, stability, pressure, microclimate

\section{INTRODUCTION}

Rock massif is a difficult to know environment on the basis of known theories of continuum mechanics, forecast its behavior in this regard being the rough and uncertain. This assertion stems from the reality that rocks massive are natural environments, discontinuous, heterogeneous and anisotropic, and consequences of these four fundamental features are numerous, raising difficult mining issues, particularly with regard to securing the stability of underground mining works and thus of safety at work. Together with these properties, throughout the period of the mining 
activity, should take account the dispersion of results, the effect of large scale research, and finally showing discontinuous nature of the environment, heterogeneous and anisotropy. The laboratory is studying small scales in size and time, while traditional geology enquire of large scales; but what mining engineer need to know is the behavior of intermediate scales, which are quite demanding and difficult to known (Bieniavski, 1967; Hoek, 1968; Brady \& Brown, 1985; Charlez, 1991; Guegen \& Palciauskas, 1992; Toderaş, 2015). To solve the problems of underground constructions, we must assess through a complete merge: laboratory research, intermediate-scale observations and all information relating to the geological and hydrogeological behavior of the rock massif, on the basis of a well-established organization chart.

In conclusion, in order to define the rock massif as a natural environment, discontinuous, heterogeneous and anisotropic, it is necessary to study two groups of properties, namely: properties of connection created in time by geological and tectonic phenomena and physical and mechanical properties, the static and dynamic deformation of the rocks and massive studied (Todorescu, 1984; Brady \& Brown, 1985; Charlez, 1991; Toderaş, 1999; Toderaş, 2014). In this sense, for the rock massif from Şuior have been carried out studies of investigation and calculation to be able to predict the deformations of the rock massif on the qualitative and quantitative bases and in order to be able to define it as a massive with a certain behavior or as a particular model behavior. In fact, the study of the geological and physical properties, strength and deformation is the first step in defining the rock massif from Şuior and solving problems of stability of the mining works performed in this massive.

\section{CHARACTERIZATION OF GEOLOGICAL AND TECTONIC ROCK MASSIF FROM SUIOR}

The rock massif should be regarded as a heterogeneous mass, showing variations and interdependencies between different types of continuity and discontinuity (Stan-Kłeczek \& Idziak, 2008). Heterogeneity of the massif from Şuior was highlighted by characteristics of connection: mineralogical composition, structure, texture, color, anisotropy and heterotopy (Todorescu, 1979; Anastasiu, 1988; Buia \& Lorint, 2011).

Observations in situ and macroscopic and microscopic measurements on polished thin sections revealed that the rock from Şuior is extremely varied (Figures $1-4$ ), can be diversified by mineralogical composition, structure, texture and color into four groups:

- group I, is the group of quartzite andesite with hornblende, which has been found by microscopic examination the presence of finely granular $\mathrm{SiO}_{2}$ embedded in a feldspar silicate microlithic mass in the form of veins, nesting, geodes and a proportion of $15-20 \%$ of plagioclase feldspars. They contain no or less than $10 \%$ clay minerals; the texture is compact and undirected, granular crystalline porphyritic structure, and the color is dark grey;

- group II, which includes andesite with hypersthene and hornblende, powerful cracked; the bonding cement is siliceous and included calcite mineral, chlorite and clay minerals in a proportion of $10-15 \%$; the structure is porphyritic, undirected texture and have a grey-dark green color;
- group III, includes rocks consist of alternating pyroclastic (breccia) and andesitic lava with hypersthene, kaolinized and sericitized rocks, strongly cracked; clay minerals are up to $25 \%$, mainly being present montmorillonite. The structure is crystalline granular porphyritic breccia, undirected texture, and the color is whitish grey towards light green;

- group IV, includes andesite group heavily influenced by hydrothermal metamorphism, including pyroxene andesite (pyroclastic, breccia) intensely metamorphosed etc. Microscopic traces can be distinguished only by hornblende and pyroxene, because the entire mass of rock is occupied by clay minerals between $25 \%$ and $60 \%$, carbonate material $10-35 \%$ accumulated as a product of alteration. Have a microgranular psephite porphyritic structure, texture being undirected. The existence of either the sericite or chlorite, or both mineral, prints a macroscopic distinguishing criterion which is color, the rocks of this group have a whitish color with a greenish tint and presents a greasy feeling at touch.
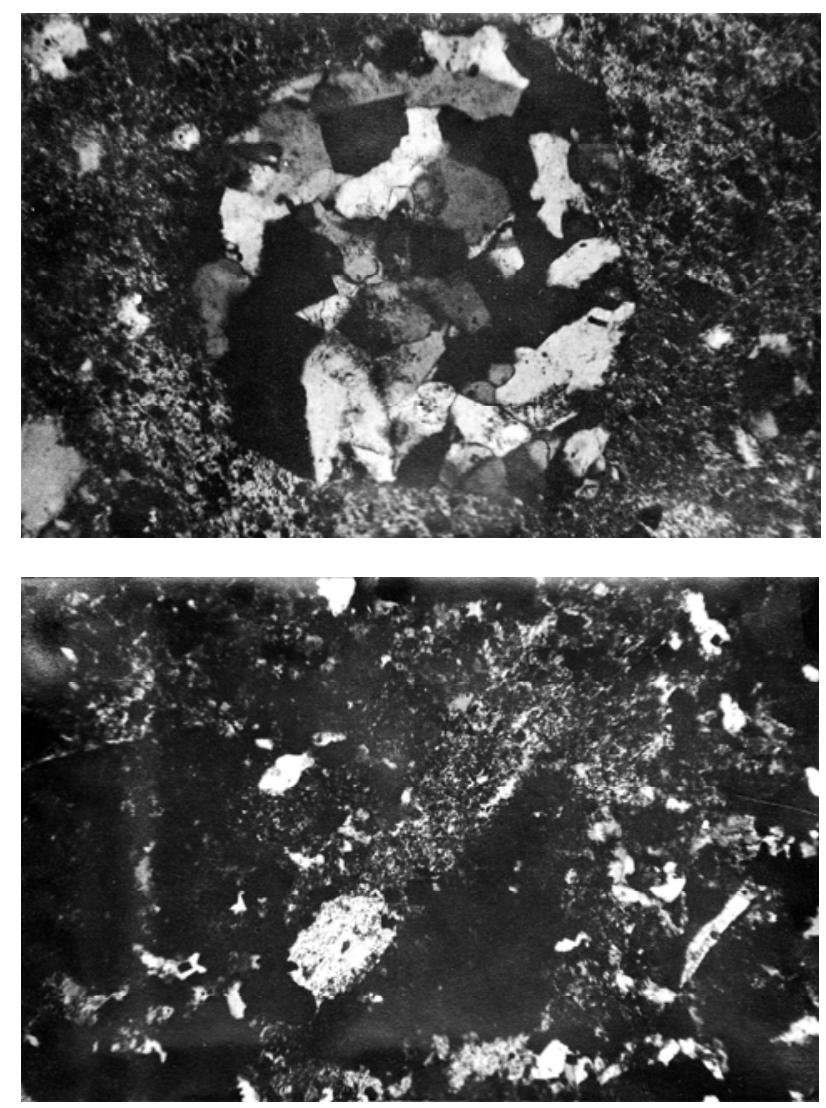

Figure 1. Psephite (quartzite) element in altered andesite and pyroxene andesite partially altered, mineralized

Thermo-differential analysis carried out confirmed the presence of clay minerals in high proportion at Şuior. These minerals are represented by kaolinite and in the case of groups III and IV being present subordinate and montmorillonite (Todorescu, 1979; Buia \& Lorint, 2011).

Argillaceous minerals appear as secondary minerals, as a product of a hydrothermal metamorphism more or less pronounced and increase of percentage as unveiling of these rocks, due to the phenomenon of alteration. 

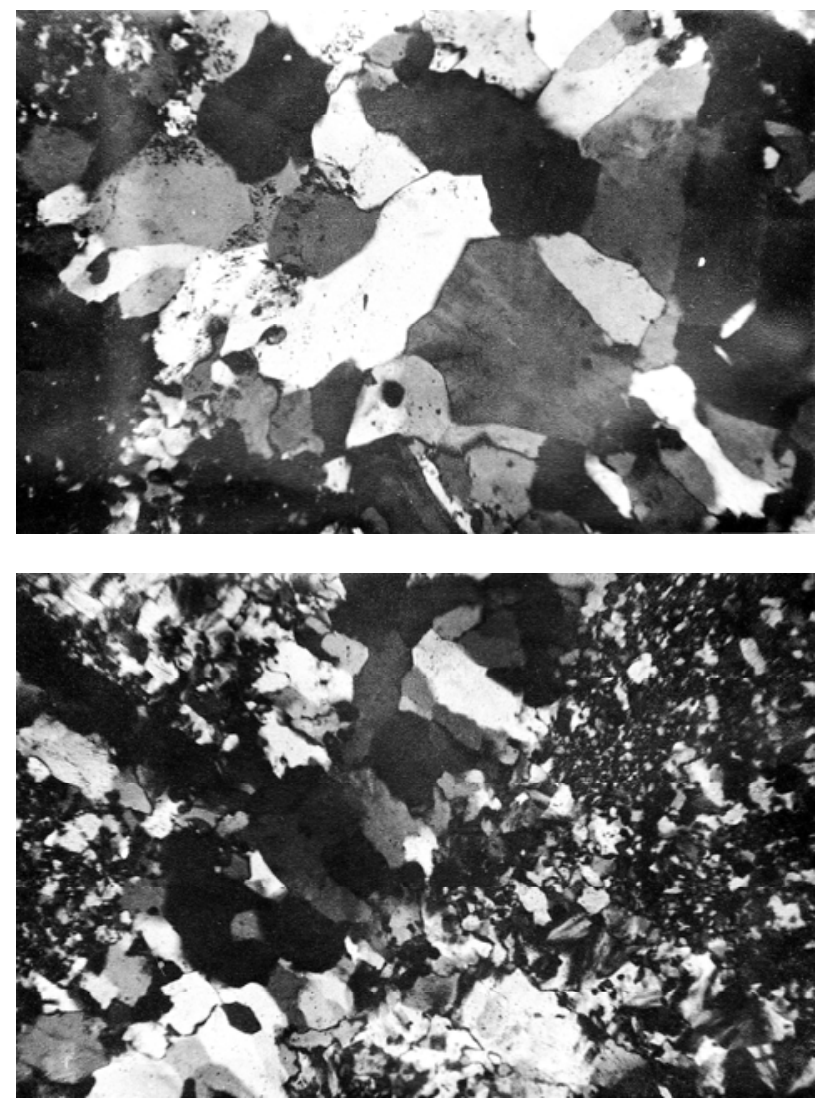

Figure 2. Volcanic agglomerate and silicified pyroxene andesite partly altered
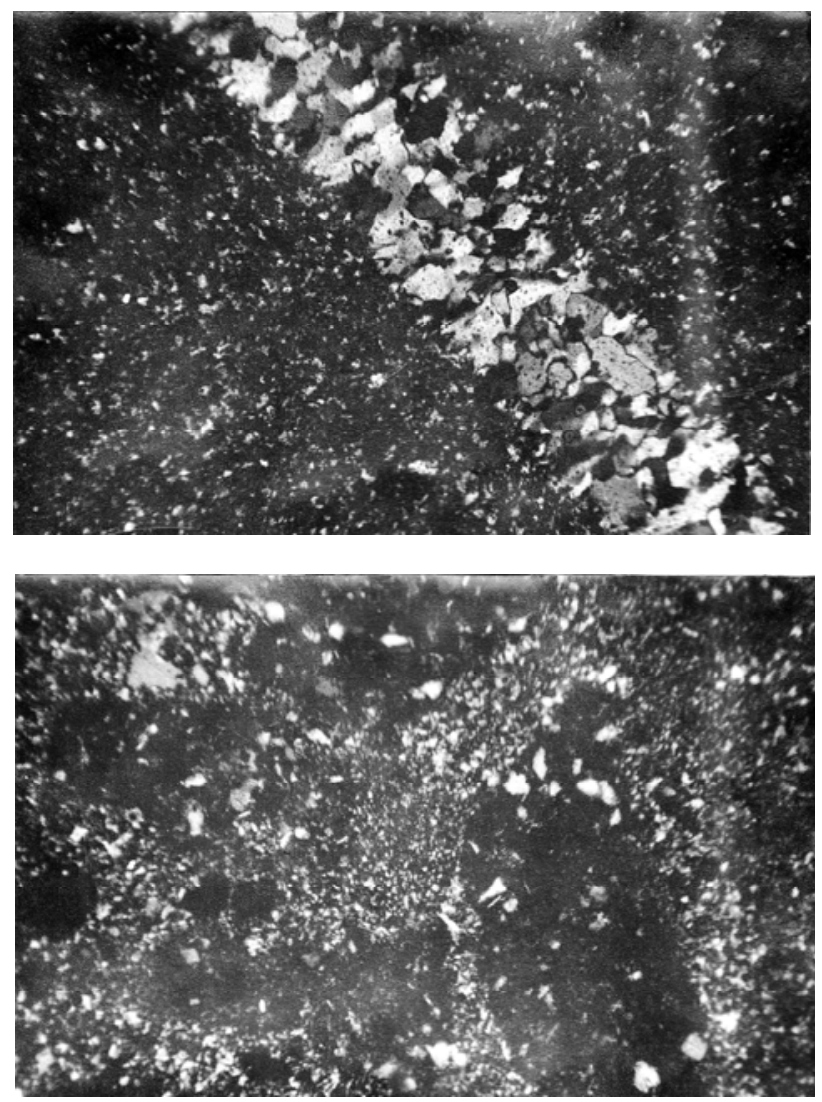

Figure 3. Hydrothermal mineralized quartzite and siliceous breccia with psephite elements of paleogene sandstone

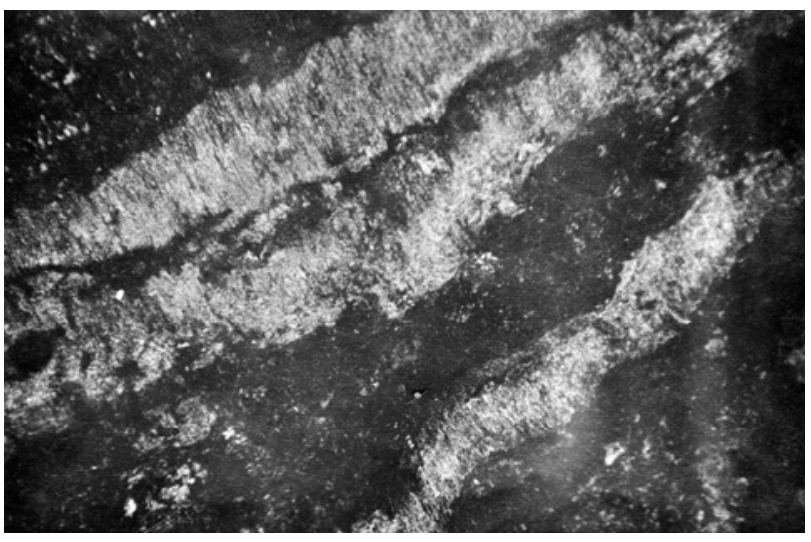

Figure 4. Quartzite andesite with hornblende

In the case of rocks from Şuior, the reality confirms the presence of a wide range of clay minerals, starting with those from kaolinite group, the hidromic and subordinate to montmorillonite, in the form of various mixtures of minerals. In terms of mining, the presence of these secondary minerals involves many dangers for technical- mining activity (Todorescu, 1979; Almăşan, 1984; Buia \& Lorint, 2011).

Due to geological and tectonic movements which took place in different geological periods, it was reached that the rock mass to be subjected to a phenomenon of deformation and occurrence of breakages, that is, to divide both crystalline scale and large scale, thereby imparting to the massif an anisotropic character. Fragmentation at crystalline scale, by physical defects created, has led to the appearance of anisotropy of constitution, known in the literature as structural anisotropy (Bieniavski, 1967; Hoek, 1968; Todorescu, 1976; Todorescu, 1979; Stan-Kłeczek \& Idziak, 2008) or anisotropy of minerals, which as the effect itself to the studied massif scale, in terms of the rock mechanics can be neglected. Independently of this anisotropy of constitution, the rock massif still has a phenomenon of anisotropy as a result of variable internal forces, depending on the massif history; the occurrence of this anisotropy is due to the overlap in time of three tensions (Barton, Lien, \& Lunde, 1974; Almăşan, 1984; Todorescu, 1984): horizontal effort created by orogeny tension, as the cause of the occurrence of faults and crazing, vertical effort due to the cover formations and thermal origin effort or spherical effort which results in the creation of variations and interdependencies between different continuity and discontinuities of the massif. This anisotropy is called tectonics or fracturing, or secondary, and it is characteristic of rock samples and rock massifs.

Summing these types of anisotropy leads to the notion of general anisotropy, which for a massif subjected to an external force field acts to change the distribution efforts and seriously reduce the strength of rocks in the directions of manifestation of this characteristic. Therefore, anisotropy, through its effect, has become a feature of particular importance for mining, because it can generate in the massif, areas and directions of increased tension; they can become dangerous if they are not taken into account. This property we considered as associated with all characteristics to define rationally the mass of rock both physically and mechanically. This category we called it anisotropy determinative, because it may be 
related to the phenomena that take place in massif, particularly the state of tension and deformation, starting from the hypothesis that mechanical properties, elastic and deformation, it changes with the orientation of the forces and that during the geological formation, the rock mass has created preferential directions after having preferential tendency to crack. In fact, this assumption proved to be consistent with the observations made in the massif on mining works in the Jiu Valley coal basin (Todorescu, 1976; Todorescu, 1979; Toderaş, 1999; Toderaş, 2014) but also at Şuior.

Heterotrophy is a feature that correspond on the one hand the lithological variations, and on the other hand as a function of the superficial phenomena of decompression and alteration. The formations from perimeter of Şuior are characterized by default heterotrophy, because they originate as a result of repeated cycles of volcanic products in the region and who created decompression phenomena accompanied by self-morphism phenomena more or less pronounced. These factors being likely to be variable in time, then the massif from Şuior is normally made up of different types of andesite.

\section{PHYSICAL AND MECHANICAL CHARACTERISTICS}

Characteristics of rock strength in general and andesite from Şuior in particular, largely depend on their physical condition and with time these parameters is changed under the influence of various external factors, the change which has influence on the stability of the rock massif and by default to underground mining works. For a comprehensive overview of mineralogical composition and the degree of activity of clay minerals existing in andesite from Şuior, the granulometric analyses were carried out by sifting and sedimentation.

The specific weight of rocks from Şuior, through the analysis of values obtained in the laboratory, it has been found that it is most stable and permanent physical property; the field value in which the specific weight may be included is between $2.66 \mathrm{gf} / \mathrm{cm}^{3}$ and $2.70 \mathrm{gf} / \mathrm{cm}^{3}$ for nonmineralized and slightly mineralized andesite towards those mineralized. Subject to alteration, andesitic rock from Şuior, changes its specific weight by approximately 5 to $10 \%$. Compared to other physical parameters, this feature can be regarded as a qualitative indicator very little variable and seems that is not influenced by the phenomenon of alteration.

Apparent specific weight of rocks of the studied perimeter from Şuior, varies considerably, with a tendency to decrease in value, depending on the degree of metamorphism and intensification of the alteration phenomenon, phenomenon which we explain through a decompaction of andesite in which the volume of pores increases.

The porosity of rocks from Şuior depends on the degree of alteration, as confirmed by the decrease of apparent specific weight with increasing porosity. For example, for $\gamma_{a}=2.14-2.15 \mathrm{gf} / \mathrm{cm}^{3}$, the porosity value was $n=21.6 \%$, and for $\gamma_{a}=2.61 \mathrm{gf} / \mathrm{cm}^{3}$, it was obtained $n=4.93 \%$, which is a decrease of the porosity with approximately 4.4 times. It was found an essential influence of porosity on the characteristics of strength, elastic and rheological.
Analyzing rocks in terms of gaps index, it is found that its value is between 1.7 and 14 , which is a relatively low gaps index, remarks which leads us to assume that very particular hydraulic behaviors may occur, such as the sensitivity of conductivity to various efforts and this fact was confirmed by observations in situ; this cannot be ignored, otherwise the risks may occur regarding the stability and safety of the works in the exploitation of the deposit.

Maximum absorption capacity in function of time was determined on the basis of Enslin method (Todores$\mathrm{cu}, 1984)$, observing that this characteristic is influenced by the type of mineral components, grain size and chemical composition. The more clay components contains the rock, the amount of water absorbed is greater.

Knowledge in terms of mechanical of a rock massif, consist of qualitative value of its reaction in relation to geometric and load changes that occur over time and achieving quantitative measurements of parameters used in the numerical calculation of the behavior of underground works (Erjanov, 1964; Hoek, 1968; Barton, Lien, \& Lunde, 1974; Todorescu, 1979; Todorescu, 1984; Toderaş, 2014). Rocks from Şuior being generally andesitic rocks with various degrees of alteration, after unveiling they are subject in time to a permanent process of alteration due to external agents and finally, we can reach a total disaggregation of rocks. Starting from these considerations, tests were carried out in laboratory in order to highlight the effect created by the action of water on rocks strength, of elastic characteristics and the measures required to reduce this effect.

Water content not only alters the mechanical strength of the rock, but also the value of elastic constants, cohesion and angle of internal friction, characteristics of plastics, etc. (Bieniavski, 1967; Belin \& Jeger, 1971; Bourbie \& Zinszner, 1985; Coussy, 1991; Berge, Wang, \& Bonner, 1993; David, Menendez, Zhu, \& Wong, 2001; Masuda, 2001; Larive, 2002). Mainly, the tests were focused on andesite strongly hydrothermal altered, purpose in which were created sets of samples, as follows: a group in which they were preserved natural humidity; a group that has been entered into the oven in order to determine the influence of relative humidity on the strength of rocks, elastic and plastic characteristics; a group of samples that have been saturated by immersion in water. Relative humidity has been evidenced by the characterization in time of rocks strength under the action of absorption phenomenon through coefficient of sustainability; to this end, in the laboratory oven have simulated the conditions of underground microclimate from Şuior, that is: temperature between $19-24^{\circ} \mathrm{C}$ and relative humidity between $75 \%$ and $100 \%$, based on the average values of these parameters, temperature $22^{\circ} \mathrm{C}$ and relative humidity of $96 \%$. In this created microclimate, the specimens were tested at different time interval, the absorption was controlled by monitoring the weight of the specimens.

The influence of free water on the elastic and mechanical properties was highlighted through the saturation coefficient, the coefficient of relative strength and coefficient of softening, the parameters set by the introduction of a series of saturation test pieces through the phenomenon of absorption, using the classical method of immersion in water and the process to determine the 
amount of water absorbed (in the latter case, the test specimen is sinking directly proportional to the water absorbed and the rock reaches maximum moisture content when it stops sinking, Figure 5).

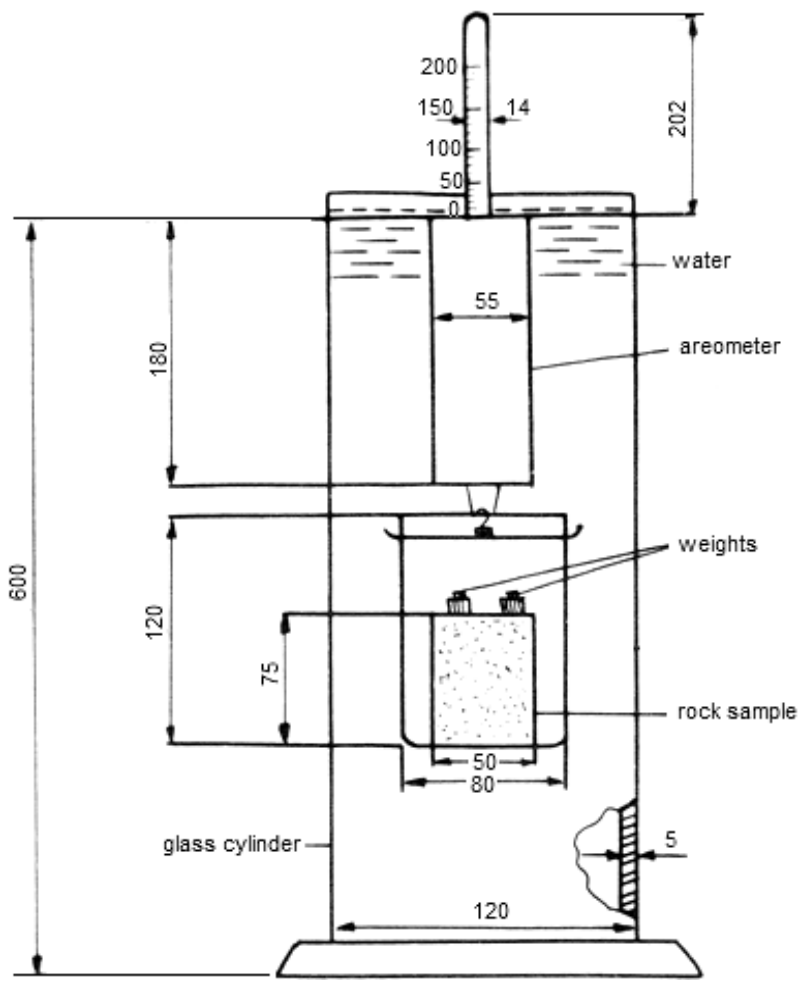

Figure 5. Determining the influence of water-rock interaction in the glass cylinder

Identifying rocks from Şuior which presents swelling properties was made on monolithic specimens in swelling device (the samples being subject both to the phenomenon of adsorption in the moisture-testing oven, Figure 6, and absorption, Figure 7) and on disturbed samples in glass cylinders in which samples were introduced and it has poured the water quantity (Todorescu, 1979; Todorescu, 1984).

In order to have the possibility of appreciating the size of reaction which would be able to stop the swelling of active rocks from Şuior, it was determined and the swelling pressure by trying the swelling under load, carried out in edometer on undisturbed rock samples with a diameter of $70 \mathrm{~mm}$ and height $20 \mathrm{~mm}$. Swelling phenomena have been studied separate aiming either volume variations or pressure that rock develops when deformation is prevented.

\section{SOLUTIONS FOR PRESERVING THE STABILITY OF ROCKS FROM SUIOR}

In order to preserve the initial parameter values of rocks from Şuior in the underground microclimate conditions, the rocks must be strengthened (at Şuior cannot be applied the consolidation by injection); therefore, we analyzed the possibilities to protect the bare surface of the rocks with different substances: guniting, applying a layer of bitumen; applying a layer of rubber; applying of synthetic resins. Guniting was applied to samples in the form of disks and cylindrical, in three layers finally reaching to a thickness of $20 \mathrm{~mm}$.
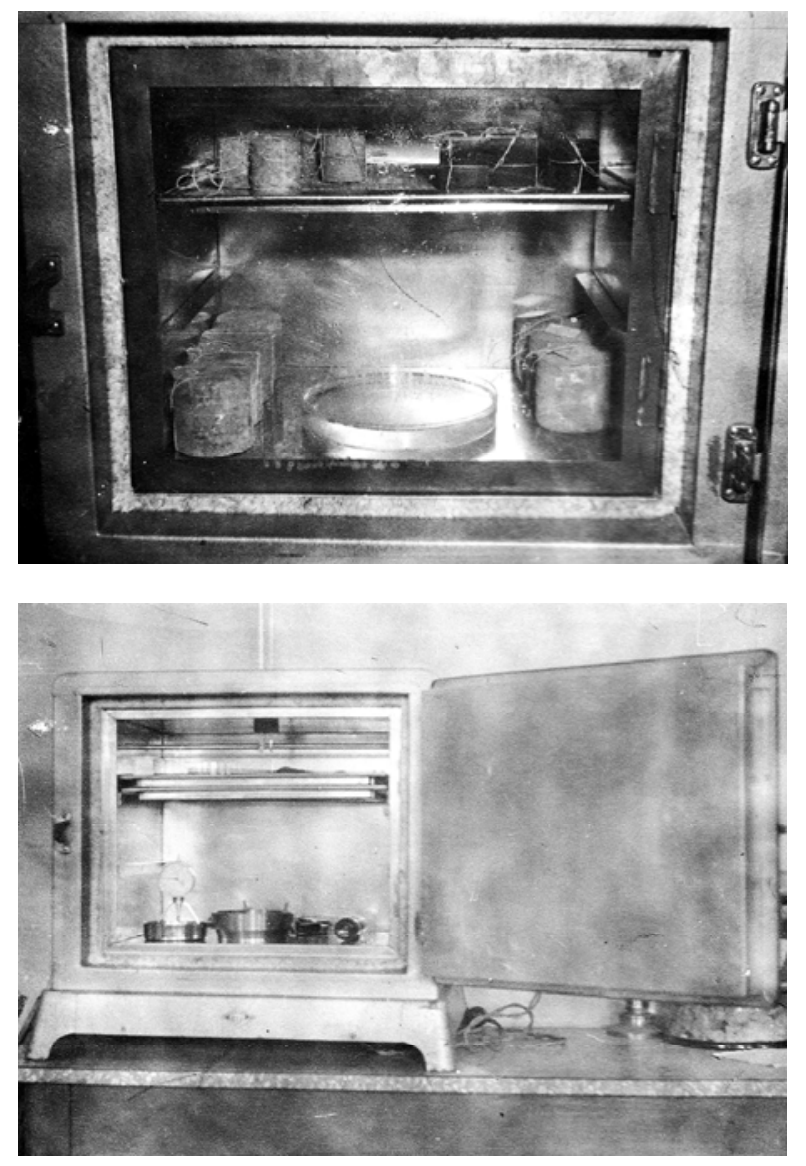

Figure 6. Determination of relative humidity and its influence on the stability of rocks from Şuior

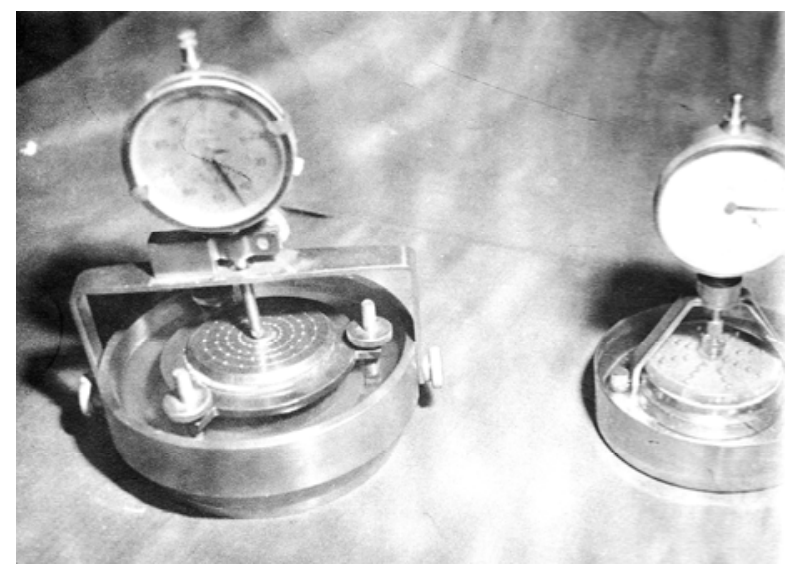

Figure 7. Testing to determine the free swelling of rocks from Şuior

Testing the gunited specimens was made after 30 days, some of them have been tested in the state as they were, other have been placed in the water to watch the absorption process and the role of gunite and part of the specimens were placed in the oven in which was created the underground microclimate.

Bituminization was achieved by applying a layer of bitumen with a thickness of $1-3 \mathrm{~mm}$ on the outer surface of the specimens, the tests being carried out in the same conditions as in the case of gunite.

Rubberizing, consisted in applying a layer of liquid rubber and monitoring the behavior of test specimens in the abovementioned conditions. 


\section{RESULTS AND DISCUSSION}

Starting from the assumption of existence of determinative anisotropy, it has been determined in the laboratory by pointed compressive test procedure and expressed through the dimensionless coefficient of anisotropy; the samples was in form of discs and oriented $\mathrm{N}-\mathrm{S}$, obtained from blocks collected from Şuior, oriented in massive. The discs had a diameter of $42 \mathrm{~mm}$ and a thickness of $2-3 \mathrm{~mm}$ and were divided in circular sectors of $10^{\circ}$ each, from 0 to $360^{\circ}$ (Fig. 8).
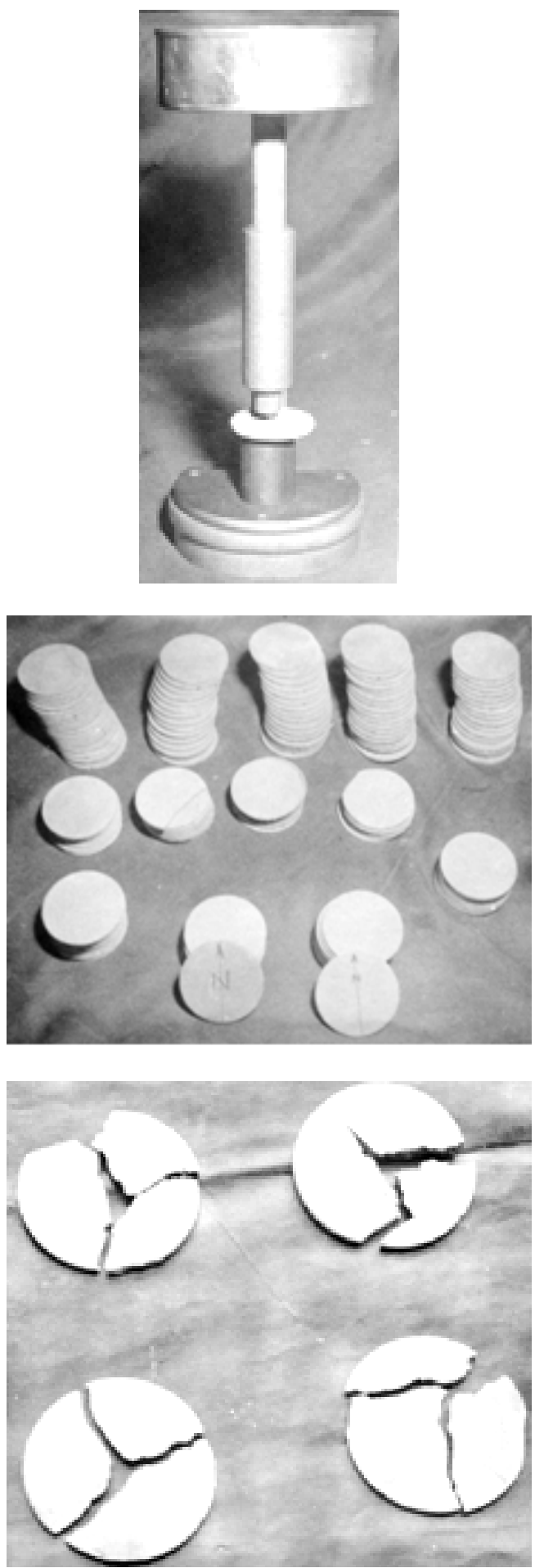

Figure 8. Testing device and test specimens in the form of discs to determine the anisotropy of rocks from Şuior
Tests on 100 disks of the same type of rock in which cracks were preferentially oriented according to directions, were obtained the number of cracks reported to $\mathrm{N}-\mathrm{S}$ direction, values processed led to the coefficient of anisotropy $(A)$. The distribution of the values obtained from tests (Fig. 9) was a somewhat symmetrical overall direction of $\mathrm{N}-\mathrm{S}$ orientation.

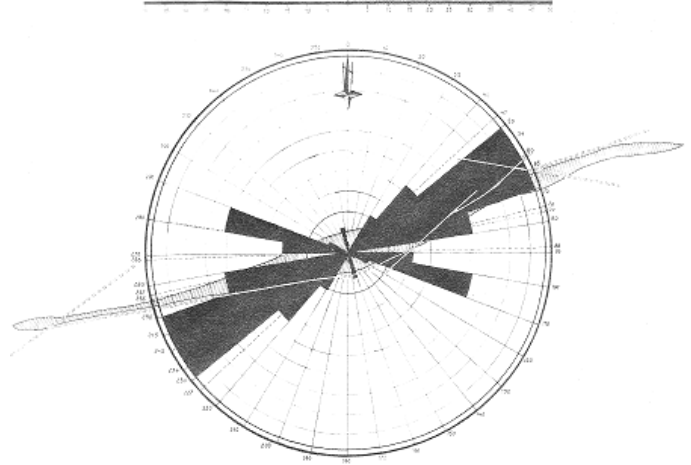

Figure 9. Circle of anisotropy for Şuior massif

The coefficient of anisotropy has been assimilated with the value of informational energy corresponding to studied structure, the limits to which this coefficient may vary being between 0 and 1 . For the massif from Şuior, the global value of the coefficient of anisotropy has resulted as 0.141 , and the amplitude increases from 0.22 to 14.1 , which is expresses by a significant degree of organization of this massive after symmetrical directions towards the $\mathrm{N}-\mathrm{S}$ direction. Massif from Suior was defined as a structure with 4 systems of surfaces for mitigating different of characteristics, and vectorial the state of anisotropy of the massif is given by a quadridimensional vector in the form of:

$$
|\vec{A}|=\left|60^{\circ}-63^{\circ} ; 107^{\circ} ; 240^{\circ}-243^{\circ} ; 287^{\circ}\right| \text {. }
$$

To highlight the degree of heterotrophy from Şuior, it was applied to a laboratory process through pointed compression. Rock samples were collected both in the direction of the deposit, and in depth, and were processed in the form of rectangular plates with a thickness of 40 $\mathrm{mm}$. One of the faces of the boards was divided into coring of square shape with dimensions of $20 \times 20 \mathrm{~mm}$; in each corner of each square, but also and in their center it was performed pointed compression test for a deformation $\varepsilon=0.25 \%$. This was achieved with the apparatus shown in Figure 10, using a ball with a diameter of $3 \mathrm{~mm}$; applying the Reichmuth's relationship, were obtained the results presented in Table 1 and Figure 11:

$\sigma_{C P}=\frac{k P}{d t}\left[\mathrm{daN} / \mathrm{cm}^{2}\right]$,

where:

$\sigma_{C P}-$ pointed compression resistance;

$P$ - applied load;

$d$ - diameter or side of the square;

$t$ - plate thickness;

$k$ - form factor and processing, $k=0.70[\mathrm{t} / \mathrm{d}]$. 

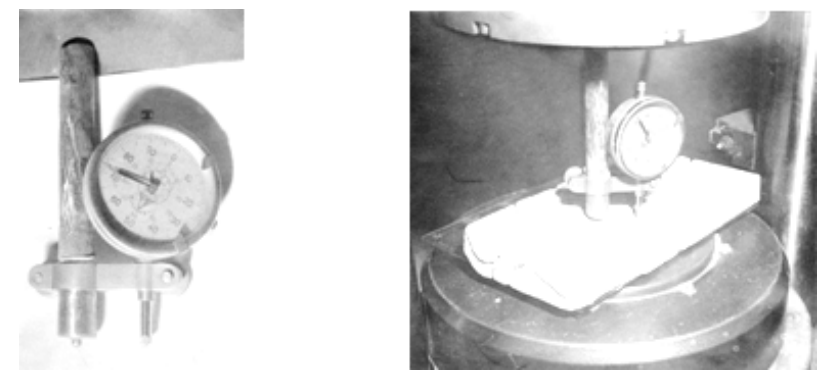

Figure 10. Experimental determination of heterotrophy of rocks from Şuior
Regarding to hydric absorption characteristics of the rocks from Şuior, we present the conclusions obtained as a result of laboratory tests and of the observations.

The constitution water in altered rocks from Şuior ranges from 5 to $35 \%$. In altered pyroxene andesite, the molecular water percentage was $16 \%$, which indicates that permeated water in the rock is hardly disposed. Adsorbed water highlights the limit from which the rock passes in the wet field from the hygroscopic condition field and from which the rocks from Şuior will change both their characteristics, as well as their stability.

Table 1. The values obtained from pointed compression test

\begin{tabular}{|c|c|c|c|c|c|}
\hline No. & $\begin{array}{c}\text { The values of pointed } \\
\text { compression resistance, } \\
\sigma_{C P}\left[\mathrm{daN} / \mathrm{cm}^{2}\right]\end{array}$ & No. & $\begin{array}{c}\text { The values of pointed } \\
\text { compression resistance, } \\
\sigma_{C P}\left[\mathrm{daN} / \mathrm{cm}^{2}\right]\end{array}$ & No. & $\begin{array}{c}\text { The values of pointed } \\
\text { compression resistance, } \\
\sigma_{C P}\left[\mathrm{daN} / \mathrm{cm}^{2}\right]\end{array}$ \\
\hline 1 & 87.50 & 41 & 157.50 & 81 & 157.50 \\
\hline 2 & 159.25 & 42 & 183.75 & 82 & 201.25 \\
\hline 3 & 210.00 & 43 & 140.00 & 83 & 148.75 \\
\hline 4 & 164.00 & 44 & 105.00 & 84 & 227.50 \\
\hline 5 & 140.00 & 45 & 175.00 & 85 & 148.75 \\
\hline 6 & 210.00 & 46 & 210.00 & 86 & 157.50 \\
\hline 7 & 140.00 & 47 & 136.50 & 87 & 157.50 \\
\hline 8 & 148.75 & 48 & 105.50 & 88 & 140.00 \\
\hline 9 & 171.50 & 49 & 183.75 & 89 & 155.75 \\
\hline 10 & 168.00 & 50 & 164.50 & 90 & 166.25 \\
\hline 11 & 157.50 & 51 & 157.50 & 91 & 140.00 \\
\hline 12 & 133.00 & 52 & 140.00 & 92 & 227.50 \\
\hline 13 & 157.50 & 53 & 175.00 & 93 & 227.50 \\
\hline 14 & 192.50 & 54 & 122.50 & 94 & 157.50 \\
\hline 15 & 157.50 & 55 & 192.50 & 94 & 140.00 \\
\hline 16 & 166.25 & 56 & 157.50 & 96 & 201.25 \\
\hline 17 & 175.00 & 57 & 105.00 & 97 & 148.75 \\
\hline 18 & 105.00 & 58 & 175.00 & 98 & 157.50 \\
\hline 19 & 218.75 & 59 & 157.50 & 99 & 175.00 \\
\hline 20 & 227.50 & 60 & 150.50 & 100 & 183.75 \\
\hline 21 & 183.75 & 61 & 210.00 & 101 & 166.25 \\
\hline 22 & 155.75 & 62 & 175.00 & 102 & 183.75 \\
\hline 23 & 192.50 & 63 & 96.25 & 103 & 218.75 \\
\hline 24 & 152.25 & 64 & 148.75 & 104 & 166.25 \\
\hline 25 & 70.00 & 65 & 190.75 & 105 & 192.50 \\
\hline 26 & 105.00 & 66 & 148.75 & 106 & 245.00 \\
\hline 27 & 227.50 & 67 & 157.50 & 107 & 183.75 \\
\hline 28 & 166.25 & 68 & 122.50 & 108 & 227.50 \\
\hline 29 & 70.00 & 69 & 148.75 & 109 & 183.75 \\
\hline 30 & 175.00 & 70 & 175.00 & 110 & 227.50 \\
\hline 31 & 157.50 & 71 & 227.50 & 111 & 157.50 \\
\hline 32 & 175.00 & 72 & 166.25 & 112 & 175.00 \\
\hline 33 & 183.75 & 73 & 157.50 & 113 & 201.25 \\
\hline 34 & 140.00 & 74 & 175.00 & 114 & 157.50 \\
\hline 35 & 105.00 & 75 & 218.75 & 115 & 175.00 \\
\hline 36 & 113.75 & 76 & 218.75 & 116 & 157.50 \\
\hline 37 & 166.25 & 77 & 175.00 & 117 & 175.00 \\
\hline 38 & 157.50 & 78 & 166.25 & 118 & 166.25 \\
\hline 39 & 201.25 & 79 & 140.00 & 119 & 192.50 \\
\hline 40 & 157.50 & 80 & 157.50 & & \\
\hline
\end{tabular}

From observations performed in underground it was also found that in situ, there is a strong process of moisture exchange between the mining air and the walls of mining works, the rock wettability decreases, but at the same time in the rock takes place a redistribution of moisture. The natural humidity of the rocks from Şuior varies within the limits of 0.1 and $5 \%$; this parameter varies depending on the distance from the deposit after a law given by an equation which represents an equilateral hyperbole, rule that we explain on the one hand by the fact that the ore moisture is higher than the surrounding rocks and therefore the deposit compensates the moisture of rocks, as a result of the massif trend towards an equilibrium of moisture content, while on the other hand the variation of humidity is also a function of the degree of self-metamorphism of rocks, which decreases as we move away from deposit (Fig. 11). 

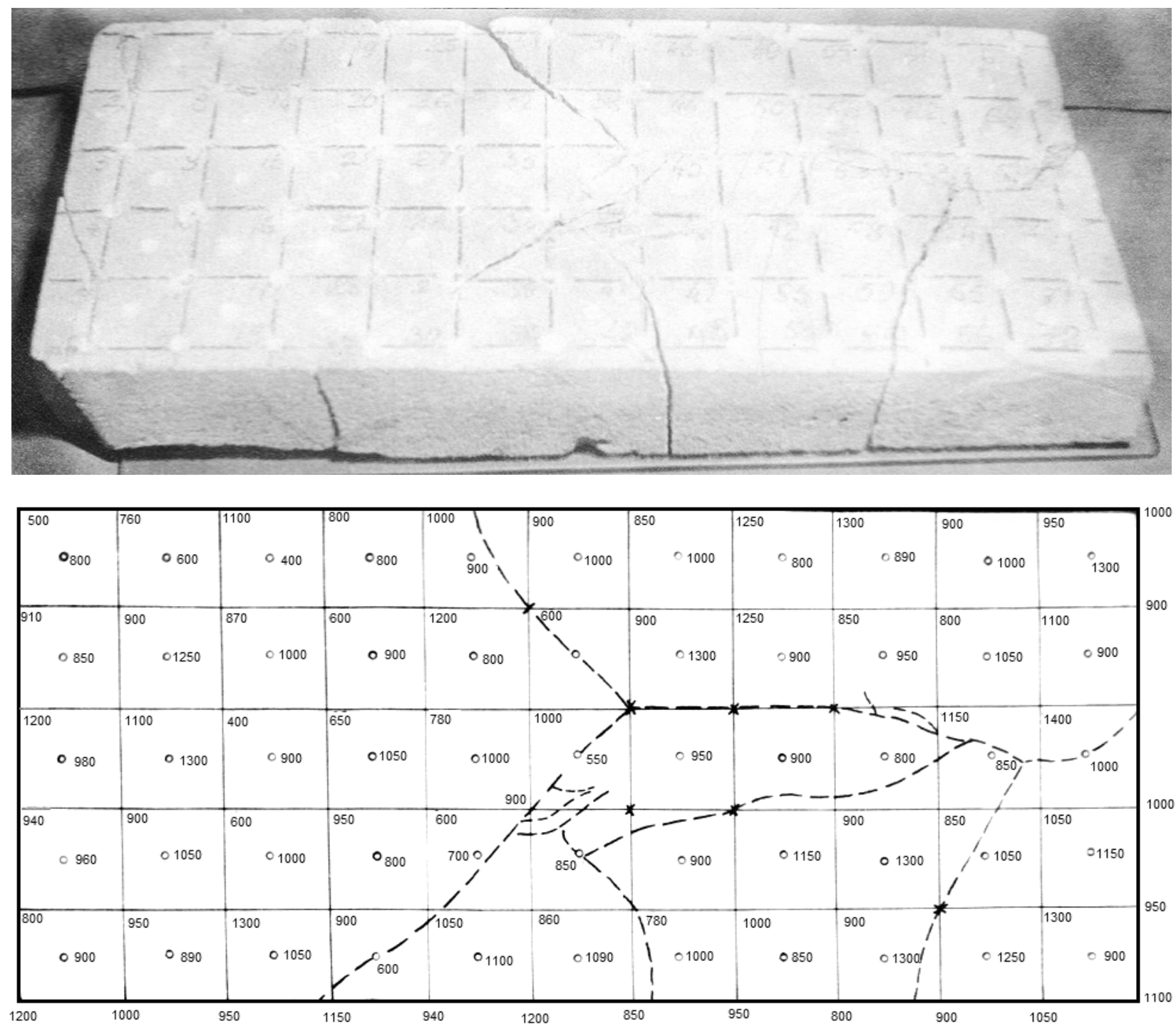

Figure 11. The heterotrophy of propylitic andesite from Şuior

Regarding to hydric absorption characteristics of the rocks from Şuior, we present the conclusions obtained as a result of laboratory tests and of the observations.

The constitution water in altered rocks from Şuior ranges from 5 to $35 \%$. In altered pyroxene andesite, the molecular water percentage was $16 \%$, which indicates that permeated water in the rock is hardly disposed. Adsorbed water highlights the limit from which the rock passes in the wet field from the hygroscopic condition field and from which the rocks from Şuior will change both their characteristics, as well as their stability. From observations performed in underground it was also found that in situ, there is a strong process of moisture exchange between the mining air and the walls of mining works, the rock wettability decreases, but at the same time in the rock takes place a redistribution of moisture. The natural humidity of the rocks from Şuior varies within the limits of 0.1 and $5 \%$; this parameter varies depending on the distance from the deposit after a law given by an equation which represents an equilateral hyperbole, rule that we explain on the one hand by the fact that the ore moisture is higher than the surrounding rocks and therefore the deposit compensates the moisture of rocks, as a result of the massif trend towards an equilibrium of moisture content, while on the other hand the variation of humidity is also a function of the degree of selfmetamorphism of rocks, which decreases as we move away from deposit (Fig. 12).

Apparent specific weight for andesitic type of rocks from Şuior, vary depending on the degree of metamorphism from 2.61 to $2.14 \mathrm{gf} / \mathrm{cm}^{3}$, or about $18 \%$, decrease which becomes even more pronounced with the emergence of the phenomenon of alteration, when this parameter reaches the value of $2.04 \mathrm{gf} / \mathrm{cm}^{3}$ (a decrease of approximately $22 \%$ ). The variation of pore volume as a result of the phenomenon of decompaction of andezites is from 1.70 for andesite with humidity below the field of moistures $\left(W_{H M}<5 \%\right)$ up to 14 very humectation andesite, that is an increase of more than 8 times. Therefore, the apparent specific weight presents an average variability, which can be assimilated with a qualitative indicator which is reduced as value with the increasing of alteration, which means that this parameter, in case of rocks from Şuior, indicates mylonite areas and degree of alteration of these rocks.

Natural moisture of strongly altered andesite from the active to very active group gives them stability $\left(W_{n}<W_{H M}\right)$, provided that it does not increase after their unveiling. 


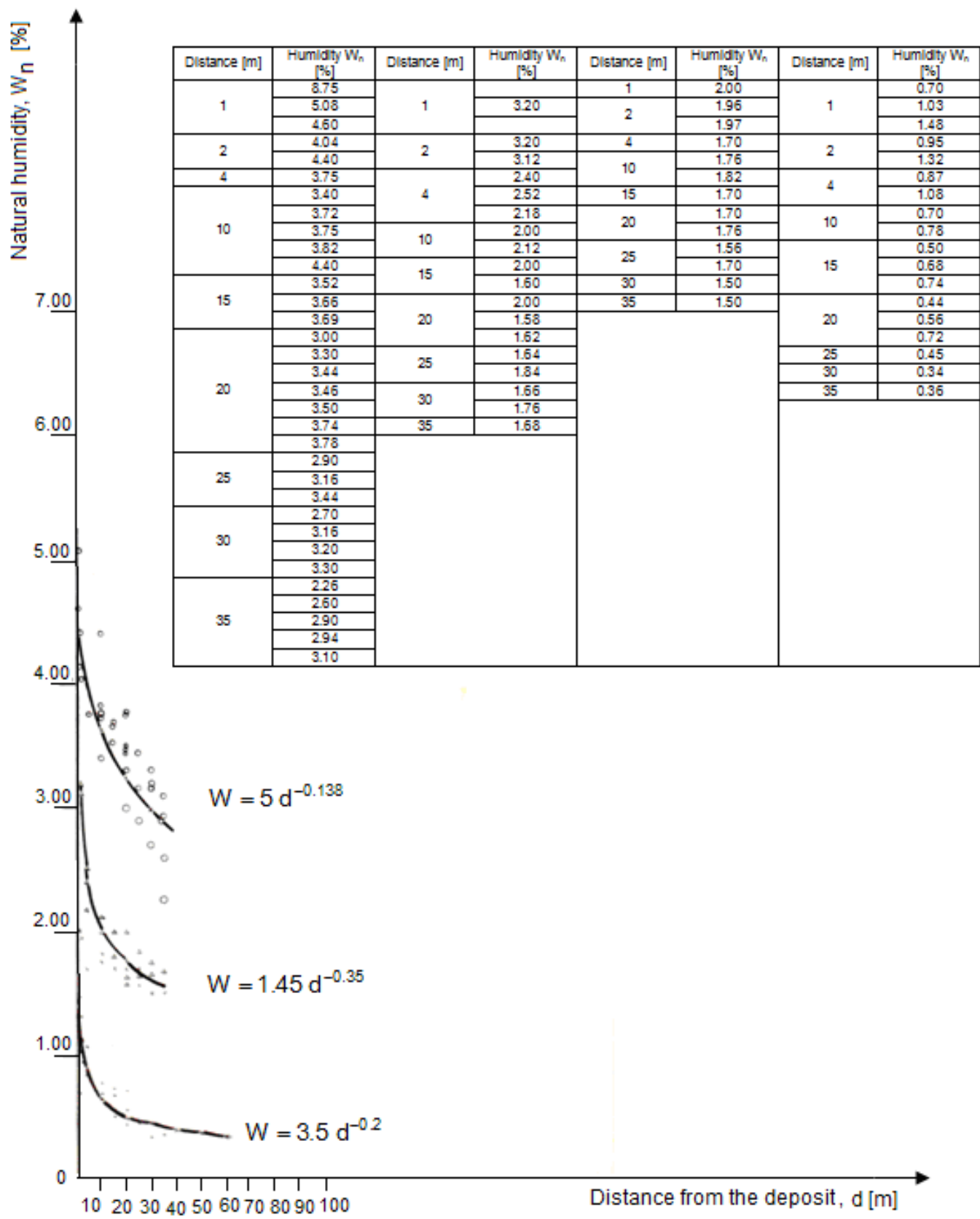

Figure 12. Humidity variation depending on the distance from the deposit

For some analyzed samples, humidity reached values of over $6 \%$, reaching $12-13 \%$, but this values does not represent the natural moisture of all rocks, but individual cases of excess moisture, excess created that places samples collection were directly related to the water source of infiltration that led as andesitic rock to reach a state of moisture close to the limit of kneading.

The absorption capacity of the water for rocks such as propylitic andesite and plagio andesite from Şuior is between 70 and $350 \%$. These rocks contain clay components created by self-metamorphism and through physical - mechanical alteration and requires special attention. With the increasing of absorption water, intensifies the phenomenon of alteration and andesite is transformed into plastic rock, waterproof and with swelling tendency, finally leading to a complete disaggregation. The disaggregation time of the rocks from Şuior vary depending on the type of andesite: andesite with hypersthene and hornblende which is introduced in the water does not disaggregates (after 90 days the absorbed moisture was maximum 6\%); andesitic rocks with a partially degree of alteration, the disaggregation period varied between 10 hours and 10 days; strongly altered andesitic rocks, of which the disaggregation period was within $10-15$ hours, after which the rock has been presented as a compact paste, consistent and the absorption moisture ranged between 10 to $15 \%$. The filtering coefficient of rocks from Şuior recorded values between $3.55 \cdot 10^{-6}$ and $5.00 \cdot 10^{-6}$, which reveals the existence of a low possibility of water circulation, which means that rocks from Şuior can be considered waterproof. Despite this conclusion, for the massif of rock from Şuior, we can speak of the existence of a hydraulic conductivities, since such a conductivity, does not depends in a practical way than by the geological boundary surfaces (macro and micro cracking) that gives a permeability higher than the rock matrix. 
In determining the coefficients of saturation, softening and relative strength through the process used to determine the amount of water absorbed, it was found that the most intensive absorption occurred in the early wetting phenomena; at the end of the test, the sinking of aerometer was very difficult to observe, which is why test specimen was immersed still about 12 hours to get precisely the completion of absorption process (Fig. 13).

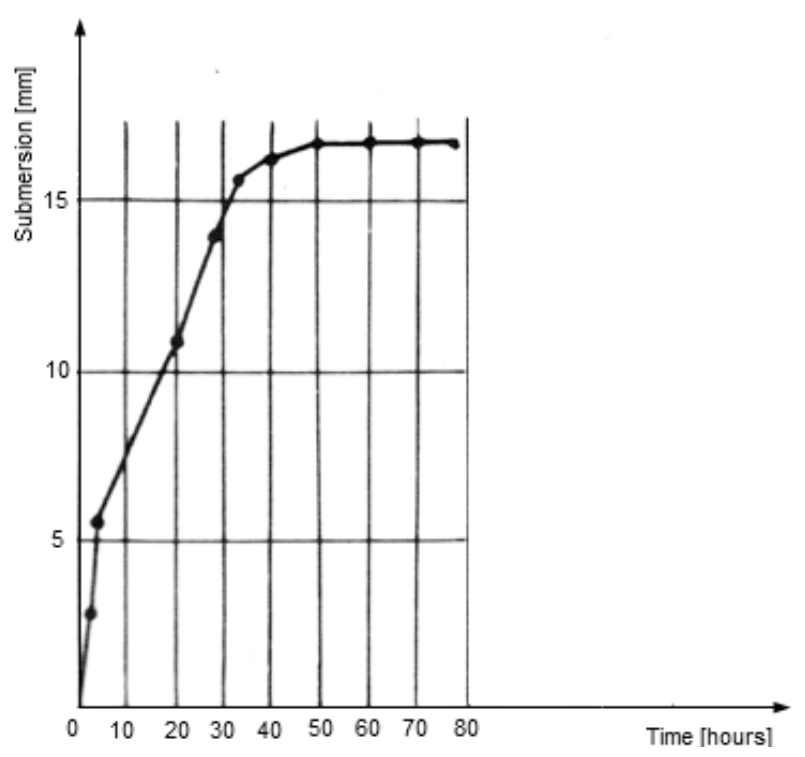

Figure 13. Determining the influence of water - rock interaction, the maximum moisture content after 48 hours: 71 hours soaking time; 17 mm maximum immersion

Looking at the graphs in Figure 14 in which it is the swelling pressure variation as compared with the deformation and if you take into account the specific swelling, it is found that the energy which can develop the active rocks of the andesite strongly hydrothermal altered type from Şuior is several times higher than non-active andesite (andesite porphyry with hipersten). Plagio andesite from Şuior with a plasticity index $I_{p}=22-61$ and a swelling pressure of $1.3 \mathrm{kgf} / \mathrm{cm}^{2}$, develops during the swelling a specific work of $138 \mathrm{gf} \cdot \mathrm{cm} / \mathrm{cm}^{2}$, while weakly metamorphosed andesite with $I_{p}=1-22$ and swelling pressure $0.51 \mathrm{kgf} / \mathrm{cm}^{2}$, presents a specific swelling work of $102 \mathrm{gf} \cdot \mathrm{cm} / \mathrm{cm}^{2}$, which is 1.35 times lower. It means that the more active rock is, the higher energy stores when it is brought into the dry state and which develops when it is moistened.

Microclimate conditions have affected the mechanical strength of the rocks, depending on their humidity. At a high initial humidity under the conditions of microclimate at Şuior, the samples have lost a certain amount of water and have increased their strength. At a low initial humidity value, the rock has absorbed water from the atmospheric moisture, decreasing its resistance. Therefore, through temperature fluctuation, the rock has been subjected to repeated cycles of absorption - desorption, which has led to a significant decrease in the mechanical resistance. The fact that in conditions of underground the temperature fluctuations are relatively low, it means that as time passes, the rock absorbs from relative humidity decreasing its strength only when the humidity is below the maximum limit of hygroscopicity. When this limit is reached, there is a balance which lowers the rock resistance, tending to a constant value. If there are fluctuations of relative humidity, then we can expect to further decrease of the rock resistance. This finding implies compulsory assessment of the presence of groundwater and their rapid evacuation and steady on the route of underground mining works.

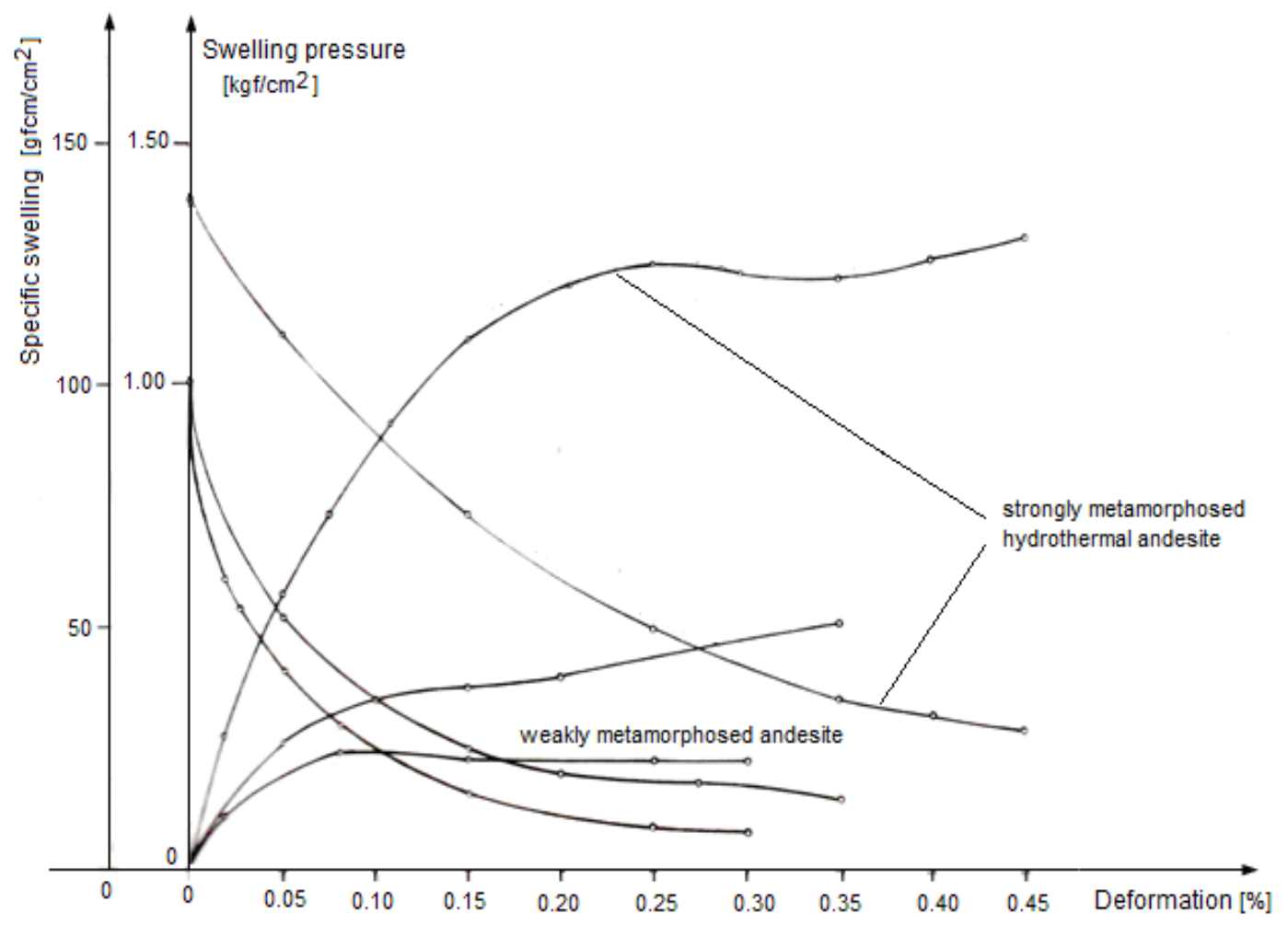

Figure 14. The pressure variation and specific swelling work of andesite from Şuior 
Alteration created by the effect of adsorbed water has great influence on the mechanical properties and deformation of rocks from Şuior; during absorption, the rocks have lost about 0.2 up to $100 \%$ of their strength and cohesion and friction inner angle came to the values that correspond to the sands mixed with gravel (cohesion of $0.63 \mathrm{daN} / \mathrm{cm}^{2}$ şi $\varphi=37^{\circ}$ ).

Analyzing the results obtained through the application of different methods of protecting the rocks, were found the following:

- by simply guniting, the tests have shown a reduction in compressive strength by $70 \%$ due to absorption of water from the mixture of gunite; samples introduced to saturation have suffered a total wetting through absorption after about 2 hours, softening coefficient increased to $86 \%$, and test specimens introduced into the oven, after 60 days, they presented a durability coefficient of only 0.013 . By simply guniting of strongly metamorphosed andesite it has reached the cracking of the gunite and swelling of rock (Fig. 15). The only rock that can apply this process is andesite with hypersthene which throughout the tests has not undergone changes of resistance, even when they came in contact with water;

- the test specimens to which has been applied the layer of bitumen were placed in water for glut, they showed a slight peeling of bitumen layer after 20 hours, a phenomenon that has advanced quite quickly, so after 6 days of keeping them in water, the specimens were damaged (Fig. 16). Unsatisfactory results were obtained on test specimens placed in the oven, in which after 30 days the sustainability coefficient was 0.04 ;

- rubber samples, after 25 days of their introduction into the water, were damaged; specimens placed in the oven, after 120 days have recorded sustainability coefficients from 0.12 to 0.14 which is slightly lower compared to the sustainability coefficients of the unprotected specimens (Fig. 16);

- protected resin specimens showed the best behavior to all attempts (Fig. 17).
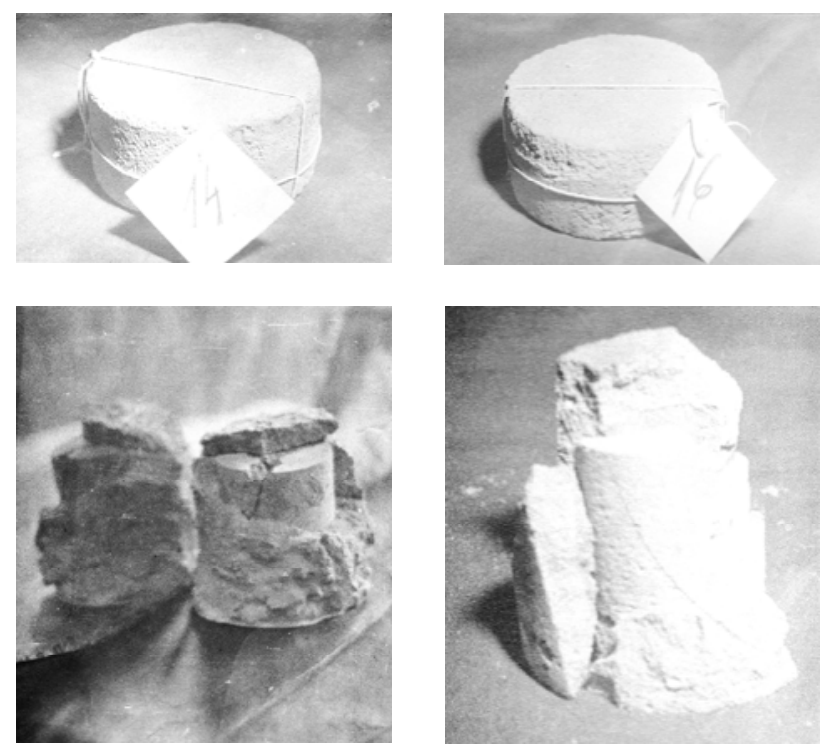

Figure 15. Guniting protection coating of andesitic rocks from Şuior
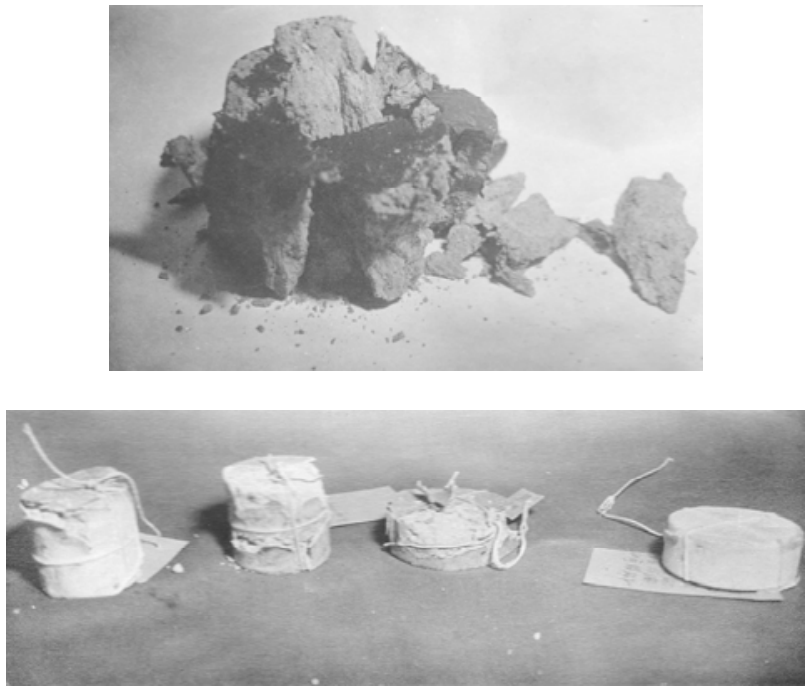

Figure 16. Protecting through rubberizing and bituminization
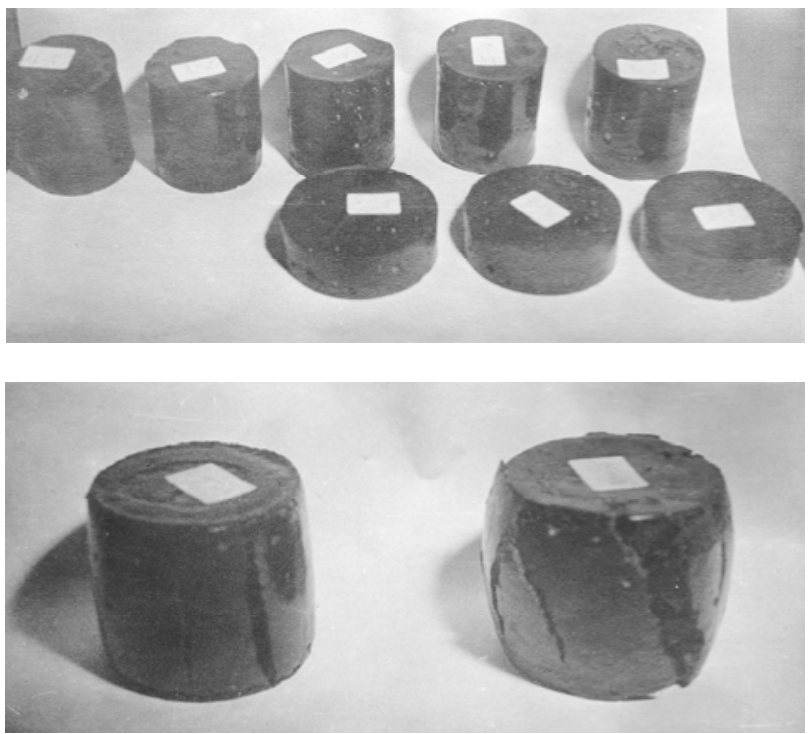

Figure 17. Synthetic resins protection of rocks from Şuior

\section{CONCLUSIONS}

Stability analysis of mining works at Şuior leads directly to the issue of stability, security and safety to underground works, which involves the development of resistant underground construction, safe and sustainable, given that the opening and preparation works are longterm goals. Based on these considerations and taking into account the depth of over $800 \mathrm{~m}$ to running mining operations from Şuior, we considered imperative the need for observation in time and analysis of the factors that contribute to the stability of these underground constructions. The stability of a mining work may be ensured either by placing it in such rocks, that the state of tension near it along with admitted technical factors do not exceed values of normal and shear stresses, or by choosing a complex of technical factors to ensure stability of mining works in concrete geological conditions. Direct observations and measurements of the works have led to the conclusion that the rock massif from Şuior is characterized by complex geological conditions: the altered rocks with low resistance, water flow, cracks and a high degree 
of tectonics. Types of andesitic rocks exhibit varying degrees of alteration and therefore different percentages of clay minerals.

Anisotropy is a consequence of the rocks structure and the massif discontinuity planes which is confirmed by the experiments and observations made at Şuior, where without exception, all are presented placed after the fundamental directions of the structure of the region considered. Diaclases and faults have created a distribution of interstitial cracking and consecutive alteration, following special orientation, materialized by quadri dimensional vector determined.

Determinative anisotropy, it appears as a decreasing factor of rocks isotropy, thus becoming a linear arrangement of the rock massif properties. Heterotrophy, regarded as a superficial phenomenon at Şuior, appeared due to decompression which led to the opening of fissures and cracks that allowed water circulation and andesite were processed through a combination of physical and chemical processes (degradation of feldspar in clay minerals) in andesite more or less altered, transformation whose result is an important loss of cohesion. At Şuior, meet areas of decompressed superficially altered andesite, unaltered areas and deep compressed areas.

The wet state condition affects the quality of solidity of rocks and their rheological behavior. Increasing moisture leads to decrease in the solidity of rocks, leading to changes in air temperature of mine through oxidation processes that it creates, and finally determines the cession of rocks around the mining works. The gaps index, through its interdependence with other characteristics of rocks from Şuior, is an indicator of qualitative assessment, through which can be achieved a direct linearity between the different geological classification of rocks and the technical - mining imposed by the necessities, but also a correlation between the main physical characteristics with the group of mechanical, elastic and rheological properties of rock. Atterbergher's limits established for strongly altered andesite have highlighted the existence of extremely large differences between the values of flowing humidity and natural moisture, difference which leads us to believe that it is possible that by isolating these rocks towards the sources of water, they maintain their status, allowing them to take over the efforts.

Rocks from Şuior located in the wet field and subjected to efforts, suffered a process of irreversible deformation; strong granules of the silicon component minerals, due to the destruction of crystalline cement of feldspar and transformation into secondary minerals, products of alteration, they remained as a viscous suspension, and the elastic connections in intact phase of the massif are few, in which case the rock behavior we can assimilate as elastic-viscous. Under the influence action of water and underground climate, most of the rocks, with the exception of porphyritic andesite with hipersten, degrades and reduces its mechanical strenghts and elastic characteristics. In order to maintain these rocks to initial parameters, methods will be used to protect, to strengthen. For the rocks from Şuior, protecting with synthetic resin is the optimal method, which is confirmed by the good behavior of the resins as insulating protection in order to maintain the characteristics of these unaltered rocks.

\section{ACKNOWLEDGEMENTS}

This work was developed from a theoretical and experimental study on the rocks and mine workings in the northern mining area of Romania, Suior perimeter. We thank to our colleagues geologists, dr. Grigore Buia and dr. Csaba Lorint, from the department of Environmental Engineering and Geology for their support in interpreting the measurements results on macroscopic and microscopic of thin sections performed on the analyzed rocks. We would also like to show our gratitude to the University of Petrosani which provided the necessary equipment to perform all laboratory tests.

\section{REFERENCES}

Almăşan, B. (1984). Mineral Deposits Exploitation in Romania. Bucharest: Technical Publishing House.

Anastasiu, N. (1988). Sedimentary Petrology. Bucharest: Technical Publishing House.

Barton, N.R., Lien, R., \& Lunde, J. (1974). Engineering Classification of Rock Masses for The Design of Tunnel Support. Rock Mechanics, 6(4), 189-236. https://doi.org/10.1007/bf01239496

Belin, J., \& Jeger, C. (1971). Etude de l'influence de l'humidification Sur les Proprietes Mecaniques de Quelques Roches. Revue de L'industrie Minerale, (1), 21-30.

Berge, P.A, Wang, H.F, \& Bonner, B.P. (1993). Pore Pressure Buildup Coefficient in Synthetic and Natural Sandstones. International Journal of Rock Mechanics and Mining Sciences \& Geomechanics Abstracts, 30(7), 1135-1141. https://doi.org/10.1016/0148-9062(93)90083-p

Bieniavski, Z.T. (1967). Mechanism of Brittle Fracture of Rock. International Journal of Rock Mechanics and Mining Sciences \& Geomechanics Abstracts, 4(4), 425-430. https://doi.org/10.1016/0148-9062(67)90032-0

Bourbie, T., \& Zinszner, B. (1985). Hydraulic and Acoustic Properties as a Function of Porosity in Fontainebleau Sandstone. Journal of Geophysical Research, 90(B13), 11524-11532. https://doi.org/10.1029/jb090ib13p11524

Brady, B.G.H., \& Brown, E.T. (1985). Rock Mechanics for Underground Mining. London: Georges Allen \& Unwin.

Buia, G., \& Lorint, C. (2011). Geology. Petroşani: Universitas Publishing House.

Charlez, Ph.A. (1991). Rock Mechanics. Paris: Edition Technip.

Coussy, O. (1991). Mécanique des Milieux Poreux. Paris: Edition Technip.

David, C., Menendez, B., Zhu, W., \& Wong, T. (2001). Mechanical Compaction, Microstructures and Permeability Evolution in Sandstones. Physics and Chemistry of the Earth, Part A: Solid Earth and Geodesy, 26(1-2), 45-51. https://doi.org/10.1016/s1464-1895(01)00021-7

Erjanov, J.S. (1964). Teoria Polzucesti Gornâh Porod $i$ ee Prilojenia. Alma-Ata: Nauka.

Guegen, Y., \& Palciauskas, V. (1992). Introduction à la Physique de Roches. Paris: Hermann.

Hoek, E. (1968). Brittle Failure of Rock. Rock Mechanics in Engineering Practice. London: J. Wiley.

Larive, E. (2002). Etude Experimentale des Roches a Tres Faible Permeabilite par la Mise en Oeuvre d'un Permeametre de Precision. PhD. Université Montpellier II Sciences et Techniques.

Masuda, K. (2001). Effects of Water on Rock Strength in Brittle Regime. Journal of Structural Geology, 23(11), 1653-1657. https://doi.org/10.1016/s0191-8141(01)00022-0

Stan-Kłeczek, I., \& Idziak, A.F. (2008). Anisotropy of Elastic Properties of Rock Mass Induced by Cracks. Acta Geodynamica and Geomaterialia, 5(2(150)), 153-159. 
Toderaş, M. (1999). Research on the Characterization of the Rheological Behavior of Rocks in the Jiu Valley Basin and Its Implications in The Mining Main Horizontal Stability. $\mathrm{PhD}$. University of Petroşani.

Toderaş, M. (2014). Rock, Soils and Underground Construction Mechanics. Petroşani: Universitas Publishing House.

Toderaş, M. (2015). Rocks Rheology in the Stability of Underground Mining Works. Study Case: Sedimentary Rocks from Jiu Valley Basin, Romania. Saarbrücken: Scholars' Press.
Todorescu, A. (1976). Anisotropy and Heterotropy Study for E.M. Dâlja, Valea Jiului. Scientific Session: Institute of Mines Petroşani.

Todorescu, A. (1979). Study of Pressure Regime Around Horizontal Mine Workings and Assessment of Optimal Supporting Systems at E.M. Şuior. Research Contract, 1974-1979.

Todorescu, A. (1984). Properties of Rocks. Bucharest: Technical Publishing House.

\section{ABSTRACT (IN UKRAINIAN)}

Мета. Утворення коливань відносної вологості призводить до подальшого зниження опору порід i, як наслідок, стрімкого підняття грунтових вод у гірських виробках. Для андезитових, сильно гідротермальних порід було виявлено необоротне явище впливу вологості на їх міцність, в той час як це явище супроводжується зміною порід за структурою і складом. Природний вологовміст при насиченні й коефіцієнт абсорбції вивчених зразків породи варіювалися у значних межах, середнє поглинання кінетичної енергії шляхом зміни одного типу порід до іншого, деякі породи не могли досягти ступеня насичення, оскільки вони були дезагреговані.

Методика. Встановлення характеристик гірських порід родовища Шуйор у контексті умов підземного мікроклімату та їх взаємодії з водою, беручи до уваги визначальну анізотропію й ступінь гетеротрофії.

Результати. Деякі гірничі виробки з прямими закріплюючими бока профілями, склепінчастою покрівлею й незакріпленою підошвою були проведені у породах з вираженими тенденціями до погіршення й пучення; враховуючи, що породи містять вставки каолінового андезиту, проявляється тенденція до здимання підошви, що вимагає використання круглих і підковоподібних профілів із закритою підошвою. Спостереження показали, що деформація підошви обумовлена не лише тим фактом, що виробки розташовані в породах з низьким опором, але також і тим, що вода, накопичуючись в підошви цих виробок, за короткий період часу змінює механічні властивості порід. Здимання підошви є наслідком інтенсивних аква-породних сил, що чинять ефект неправильної відносної співвісності підошви, руйнівного впливу на фундамент і опорну базу, що викликає дію горизонтального зміщення до внутрішньої частини виробки, призводячи до розбалансування гірничого кріплення.

Наукова новизна. Для порід родовища Шуйор охорона виробок синтетичною смолою $\epsilon$ оптимальним способом, що підтверджується якісним режимом роботи смол як ізолюючого захисту для підтримання характеристик цих незмінних порід.

Практична значимість. Під впливом водного й підземного клімату значна частина гірських порід, за винятком порфірового андезиту з хіперстеном, втрачає свої властивості, механічну міцність та пружність. Для підтримання цих порід у початковому стані представлені методи будуть використовуватися для охорони й укріплення. Зміна порід за структурою і складом, створена водним впливом, значно впливає на міцнісні та деформаційні характеристики, які чинять прямий вплив на стійкість гірничих виробок, пройдених в породах родовища Шуйор.

Ключові слова: анізотропія, перетворення, вологість, здимання, стійкість, тиск, мікроклімат

\section{ABSTRACT (IN RUSSIAN)}

Цель. Образование колебаний относительной влажности приводит к дальнейшему снижению сопротивления пород и, как следствие, стремительному поднятию грунтовых вод в горных выработках. Для андезитовых, сильно гидротермальных пород было обнаружено необратимое явление влияния влажности на их прочность, в то время как это явление сопровождается изменением пород по структуре и составу. Естественное влагосодержание при насыщении и коэффициент абсорбции изученных образцов породы варьировались в больших пределах, среднее поглощение кинетической энергии путем изменения одного типа пород к другому, некоторые породы не могли достичь степени насыщения, поскольку они были дезагрегированы.

Методика. Установление характеристик горных пород месторождения Шуйор в контексте условий подземного микроклимата и их взаимодействия с водой, принимая во внимание определяющую анизотропию и степени гетеротрофии.

Результаты. Некоторые горные выработки с прямыми закрепляющими бока профилями, сводчатой кровлей и незакрепленной почвой были проведены в породах с выраженными тенденциями к ухудшению и пучению; учитывая, что породы содержат вставки каолинового андезита, проявляется тенденция к пучению почвы, которая требует использование круглых и подковообразных профилей с закрытой почвой. Наблюдения показали, что деформация почвы обусловлена не только тем фактом, что выработки расположены в породах с низким сопротивлением, но также и тем, что вода, накапливаясь в почве этих выработок, за короткое период времени изменяет механические свойства пород. Пучение почвы является следствием интенсивных аква-породных сил, имеющих эффект неправильной относительной соосности почвы, разрушающего воздействия на фундамент и опорную базу, что вызывает действие горизонтального смещения к внутренней части выработки, приводя к разбалансировки горную крепь.

Научная новизна. Для пород месторождения Шуйор охрана выработок синтетической смолой является оптимальным способом, что подтверждается качественным режимом работы смол как изолирующей защиты для поддержания характеристик этих неизменных пород. 
Практическая значимость. Под воздействием водного и подземного климата существенная часть горных пород, за исключением порфирового андезита с хиперстеном, теряет свои свойства, механическую прочность и упругость. Для поддержания этих пород в исходном состоянии представленные методы будут использоваться для охраны и укрепления. Изменение пород по структуре и составу, созданное водным воздействием, оказывает значительное влияние на прочностные и деформационные характеристики, которые оказывают прямое влияние на устойчивость горных выработок, пройденных в породах месторождения Шуйор.

Ключевые слова: анизотропия, преобразование, влажность, пучение, устойчивость, давление, микроклимат

\section{ARTICLE INFO}

Received: 9 August 2017

Accepted: 4 September 2017

Available online: 30 September 2017

\section{ABOUT AUTHORS}

Mihaela Toderas, Doctor of Philosophy, Professor of the Mining Engineering, Surveying and Civil Engineering Department, University of Petrosani, 20 University St, 332006, Petrosani, Romania. E-mail: toderasmihaela@yahoo.com

Roland Moraru, Doctor of Philosophy, Professor of the Management and Industrial Engineering Department, University of Petrosani, 20 University St, 332006, Petrosani, Romania. E-mail: roland_moraru@yahoo.com 